\title{
Clinical Supervision and Principal Leadership's Influence on Teacher Performance
}

\author{
Leni Mardiah \\ SMA Negeri 19 Palembang, Indonesia \\ Email: lenimardiah30@gmail.com \\ Nur Ahyani \\ Universitas PGRI Palembang, Indonesia \\ e-mail: nurahyani@univpgri-palembang.ac.id \\ Mahasir \\ Universitas PGRI Palembang, Indonesia \\ e-mail: mahasir@univpgri-palembang.ac.id \\ Article History: Received on 10 December 2021, Revised on 25 January 2022 \\ Published on 22 February 2022
}

\begin{abstract}
The purpose of this study is to evaluate and analyze: (1) the impact of clinical supervision on teacher performance; (2) the impact of principal leadership on teacher performance; and (3) the impact of clinical supervision and principal leadership combined on teacher performance. This is a quantitative study utilizing an ex post facto technique. This study was carried out at SMA Sub Rayon 18 Palembang, with a population of 265 teachers, and 159 persons were chosen at random as samples. Questionnaires are used to collect data. The validity test employs construction and content validity, and the reliability test use Cronbach's Alpha. The normality, linearity, multicollinearity, and hesteroscedasticity tests were used to examine the test criteria, and the data were analyzed using multiple linear regression approaches. The findings revealed that clinical supervision and principal leadership had a good and substantial influence on teacher performance.
\end{abstract}

Keywords: Clinical Supervision, Principal Leadership, Teacher Performance

\section{A. Introduction}

The principal, instructors, students, school administrative personnel, curriculum, and the environment are all interconnected aspects of a school, which is a formal educational institution where teaching and learning activities take place. Because the teacher is the "key person" who works directly with students in the teaching and learning process, the teacher plays a very essential role in the execution of the learning process. A teacher must be able to establish a comfortable learning environment in order for students to be completely engaged in learning activities and for educational goals to be met successfully and quickly (Utami, 2017). A positive relationship between instructors and students will increase educational quality and student success.

Teachers are an important factor that greatly influences the occurrence of good educational processes and outcomes; in order to achieve this, the quality of teaching teachers must continue to be improved, so that teachers have high motivation in teaching and good individual performance can be achieved, because good teacher performance will produce graduate 
Volume 3 (2) 2022

E-ISSN: 2723-6919 P-ISSN: 2746-0827

participants who will receive quality education. Qualified education staff, essentially education employees who are accountable and can address problems promptly and accurately, is one component that plays a role in increasing the quality of education in a positive manner. Educators have a strategic role in the development of students' knowledge, skills, and character. As a result, professional educators are required to carry out their jobs properly in order to produce competent pupils.

Professional instructors are supported by good performance; teacher performance is inextricably linked to the principal's function as a motivator for developing teacher talents and performance. As a result, competent and dependable principal leadership is required to build a work process that may inspire students to study more actively, so improving student learning attainment in accordance with the goals set out in the school's vision and purpose. To do this, teacher performance must be enhanced, and one of the influential variables is the principal's leadership conduct.

The principal is one of the most important components of education in terms of boosting educational quality; as a school leader and innovator, the principal must be able to set a good example for teachers. According to Mulyasa (2019), the principal is a component of instructional material that influences the improvement of teacher performance. The school principal is in charge of instructional activity execution, school management, coaching other educational employees, and the usage and upkeep of facilities and infrastructure. According to the findings (Kristiawan et al, 2019), if the principal wants his school to be ready for the MEA, the approach should include updating teachers' competence, upgrading students' competence, establishing curriculum, and enhancing infrastructure. However, the interaction between peer teachers and principals is currently more bureaucratic and administrative, which discourages the formation of comfortable circumstances between principals and instructors. According to (Majid, 2016), extensive efforts are required to develop competent instructors since teachers do not currently have the skills to support teacher performance.

According to (Santi, 2019), increasing teacher competence requires attention to teachers not only through training activities, upgrading, and providing opportunities for learning, but also by providing motivation, increasing work discipline, providing direction through supervision, providing incentives, and providing decent salaries. In addition to the principal's leadership, teacher performance supervision can have an impact on teacher performance. The act of supervising instructors is referred to as supervision. Principals must understand their subordinates in order to encourage the subordinates they oversee, according to (Kristiawan et al., 2019). As a result, a person who performs supervisory responsibilities and tasks must have understanding of leadership theory that supports supervisory activities in order to assess the effectiveness of a school administration.

According to (Saniyem et al., 2020), one technique to increase teacher effectiveness is through monitoring. After supervising the principal, he will be aware of the teacher's inadequacies in teaching and learning activities. However, in fact, supervision has not been considered a primary activity that school principals must carry out in order to enhance teacher performance; rather, supervision activities are simply a school routine in order to complete school certification. Academic supervision is required in order to carry out supervision and advice in order to increase teacher quality in a sustainable manner (Renata et al., 2018, Lian \& Fitria, 2020). 
Field supervision is often less successful since it tends to merely watch rather than oversee, and there is no follow-up outcome after the application of supervision. This follow-up exercise is critical for identifying persistent difficulties experienced by educators throughout teaching and learning activities. Clinical supervision is the process of identifying persistent issues that are causing teacher performance to deteriorate. Clinical supervision works closely with educators and focuses on enhancing educators' organized instruction.

According to study (Isherwood, 1983), a supervisor trained to be either direct or indirect with a teacher during lesson analysis found that either strategy resulted in a change in teacher classroom conduct in an intended direction when compared to a control condition when no supervision was used. Supervision by qualified supervisors will result in changes in teacher behavior in the desired direction, namely improved performance as compared to the lack of supervision. The principal's power in the school will affect the supervisory relationship between the principal and the teacher, the teacher's loyalty to the principal, and the teacher's sense of work satisfaction.

Researchers discovered several problems based on observations and interviews with curriculum representatives and teachers at SMA Sub Rayon 18 Palembang, including school principals who rarely supervise, the implementation of supervision is only left to the deputy principal, principals who are not skilled in supervising, principals who have not been able to supervise in accordance with the implementation of proper supervision, namely helping teachers over time. Another issue is that instructors are frightened to be observed and are awkward/stiff during supervision activities; if this scenario is not addressed by the principal, clinical supervision will be impossible to carry out.

When academic supervision is scheduled, the teacher prepares effectively for learning administration; nevertheless, when there is no supervision activity, the teacher is less prepared to carry out teaching and learning activities. Some teachers lack confidence in learning because they do not master the teaching materials and do not master the class, because the teacher still conveys material in a monotonous and unattractive manner for students, the use of learning media is limited to supervision, and the teacher does not display an appealing personality for students. student. Based on these flaws, the teacher should communicate the issues and challenges to the principal as the supervisor in order to find answers to the problems he experiences. However, in practice, instructors are hesitant to communicate their teaching concerns, therefore clinical supervision activities cannot be carried out.

Some of these issues are critical to address since teacher competency has a significant impact on the quality of teaching and learning in schools, and the role of school leaders in enhancing teacher competence must, of course, be given more consideration. The researchers are interested in doing more study on the Effect of Clinical Supervision and Principal Leadership on Teacher Performance based on the phenomena and difficulties that emerge.

\section{B. Methods}

This is a quantitative study with an ex post facto technique, which means that research is carried out to examine previous occurrences and then look to the past via data to uncover things that precede or determine probable causes and consequences for an event under investigation (Sugiyono, 2019). This research is also known as correlational research, which is a study 
Volume 3 (2) 2022

E-ISSN: 2723-6919 P-ISSN: 2746-0827

conducted to determine the relationship between two or more variables, namely research that aims to find the effect or correlation between one variable and another, namely the effect of clinical supervision and principal leadership on the performance of high school teachers in SubRayon 18 Palembang.

The population in this study consisted of all 265 instructors who teach in SMA in Sub-Rayon 18 in 2021. The population, according to (Widiyanto, 2010), is a group or collection of things or objects that will be generalized from the study results. The sampling approach used in this study is simple random sampling, which is a method of gathering samples from members of the population at random, independent of strata in the population (Sugiyono, 2019). In this investigation, basic random sampling was carried out. According to (Bungin, 2010), the Slovin formula may be used to determine the number of samples. The data collection tool employed in this study is a questionnaire with a Likert scale, which is consistent with the quantitative approach used. According to (Riduwan, 2020), the Likert scale is a five-level ordinal scale with an estimated value of replies to each question with levels of always, ever, sometimes, seldom, and never. The researcher also did a documentation study in addition to the questionnaire. This study's data analysis approach employs basic correlation data analysis techniques and multiple linear regression with the assistance of SPSS Window Version 26. The steps of analysis implementation are as follows: 1) descriptive analysis, 2) test requirements analysis, and 3) hypothesis testing.

\section{Results and Discussion}

\section{Clinical Supervision Variable Regression Coefficient Test}

The $\mathrm{t}$-count is 8.423 , according to the coefficient table. The t-table produced a 1.975 using a two-tailed test (significance $=0.025$ ). Based on the description above, it is known that t-count $=8.423$ and $\mathrm{t}$-table $=1.957$, where $\mathrm{t}$-count $>\mathrm{t}$-table indicates that $\mathrm{Ha}$ is accepted, or that clinical supervision has a partial influence on teacher performance.

\section{Testing the Regression Coefficient of the Principal's Leadership Variables}

The t-count is 13,383 according to the coefficient table. The t-table produced a 1.975 using a two-tailed test (significance $=0.025$ ). Based on the reasoning above, it is known that $t$-count $=$ 13.383 and $\mathrm{t}$-table $=1.957$, where $\mathrm{t}$-count $>\mathrm{t}$-table, implying that $\mathrm{Ha}$ is accepted, or that principal leadership has a limited impact on teacher performance.

\section{Regression Coefficient Test}

Based on the data, the constant value of the regression equation an is 46,698 and the coefficient values of the independent variables b1 and b2 are 0.143 and 0.337 , respectively, therefore the regression equation is as follows:

$\mathrm{Y}=\mathrm{a}+\mathrm{b}_{1} \mathrm{x}_{1}+\mathrm{b}_{2} \mathrm{x}_{2}$

$=46,698+0.143 \times 1+0.337 \times 2$

$\mathrm{Y}=$ Teacher Performance

$\mathrm{X} 1=$ Clinical Supervision

X2 = Principal's Leadership 
This signifies that teacher performance has improved as a result of clinical observation and principal leadership. 1) The constant value is 46,698, implying that if clinical supervision and principal leadership are not variables, the teacher performance value is 0.143 . This signifies that the value of 0.143 is on a scale of 1 in terms of sufficiency; 2) If clinical supervision (X1) scores rise/fall by 1 (one) unit, the principal's leadership value rises/falls by 0.143 score units, assuming the principal's leadership (X2) value remains constant; 3 ) If the principal's leadership value (X2) increases by 1 (unit) score, the teacher's performance (Y) increases/increases by 0.330 unit score, provided that clinical supervision is given (X1) has a constant value.

\section{The Effect of Clinical Supervision on Teacher Performance}

Clinical supervision has a considerable influence on teacher performance, as can be observed. These findings corroborate the preliminary conclusion that clinical supervision has a considerable impact on teacher performance. According to calculations using the regression equation, if the value of clinical supervision (X1) rose by one unit score, the teacher's performance (Y) would improve by 46,698. unit score, under the condition that the clinical supervision score $(\mathrm{X} 1)$ remains constant.

The teacher meets with the principal on his own initiative and discusses his teaching problem with the principal. The teacher then agrees on the time, place, and observation instrument to be used, and the teacher discusses things that must be prepared, such as a plan for implementing learning that will be used during the time of observation, material, media, or stone tools that support the material to be taught. This first stage is critical in determining what measures will be performed during the observation. Many instructors, however, are still hesitant to meet with the principal because they are embarrassed and humiliated of the principal, and many teachers do not want to be supervised.

The principal observes and documents events that occur in the classroom to be utilized as discussion material during the feedback meeting stage. At this observation stage, the principal as a supervisor must master good supervision techniques so that important things at the observation stage are not missed. In carrying out their functions as supervisors, the principal must have skills that include skills to form a framework that will be carried out during supervision, satisfactorily attention to the teacher, focusing on students, focusing on interactions in the classroom, adjusting to initial analysis, and managing the classroom. According to Priansa et al. (2018), the principal's function in clinical supervision is that of a work partner, supervisor, coach, and motivator. Following the observation stage, the feedback meeting was held.

As the supervisor, the principal will present notes from incidents that happened during class observations and make recommendations for improvements in instructional activities. The feedback meeting stage is seldom carried out by the principal in the execution of supervision; following class observations, the teacher is not told of his flaws or weaknesses in teaching, therefore there is no change in teaching patterns before and after supervision activities.

The size of the effect of clinical supervision on teacher performance at SMA sub rayon 18 Palembang is modest, indicating that clinical supervision was not carried out adequately owing to a lack of optimal implementation of the first level. This is due to several factors, including: 1) educators' reluctance to approach the principal, which does not foster an intimate environment; 2) educators' embarrassment at expressing their weaknesses in teaching and 
satisfaction with the easy and monotonous teaching method, namely the provision of teaching materials through the teaching method. lectures and giving practice assignments; and 3) the principal's lack of skill in supervising activities. At this early stage, strong communication is required; yet, collaboration and tight and open connections between principals and teachers are not established.

To improve the educational process, teacher coaching with a clinical perspective is required. Clinical supervision should be carried out on a regular basis in order to overcome educators' weaknesses in teaching. Clinical supervision focuses on educators and principals, and interactive relationships, communication, and openness are required between educators and principals, because the success of clinical supervision is dependent on several factors inherent in principals as supervisors. Clinical supervision is necessary for teachers to improve their performance. Principals must understand the steps in carrying out supervision, particularly in clinical supervision activities, which include the pre-observation/planning level, which is important because supervisors and educators determine what is needed in the supervision process, the level of observation, and the level of feedback. Each level plays a crucial role.

The findings of this study are consistent with those of (Lestari, 2019), who concluded that clinical supervision is urgently needed by educators to improve the performance of professional teachers, and that professional teachers will have a significant impact on improving the quality of human resources. Principals can undertake teacher performance coaching in regulating the teaching and learning process through clinical monitoring. Clinical supervision by principals must be enhanced and developed via different feasible efforts and tactics in order to increase the quality and inventiveness of educators, so that it may bring advantages for enhancing the quality of education in schools. produce a good and meaningful influence on improving teacher performance, there must be an effort by educators themselves to continue to develop their competences so that they are balanced on increasing student learning outcomes to support teacher performance improvement.

Clinical supervision in its implementation focuses on enhancing quality in the teaching and learning process, with educators acting as implementers through a sequence of systematic activities beginning with introductory activities, observation activities, and feedback activities. Supervision is done to find solutions or alternatives to weaknesses that occur in the teaching and learning process; in this case, the principal must be skilled in assisting and motivating teachers to seek improvement in teaching and optimizing their roles and functions in the teaching and learning process.

The principal is very important in clinical supervision activities, such as guiding educators in selecting appropriate teaching methods, selecting the right educational media based on what students need, providing guidance in compiling the syllabus, having regular class visits for observation activities and discussing the results of these observations, and conducting joint monitoring activities on school programs. According to Kristiawan et al. (2019), the principal's function in clinical supervision activities is a) the principal as a partner, b) the principal as a supervisor, c) the principal as a coach, and d) the principal as a motivator. If the principal fulfills all of these tasks as a clinical supervisor of all educators, the outcomes will be positive and may be used to solve difficulties encountered by educators in teaching and learning activities. This is consistent with (Hasanah \& Kristiawan, 2019) theory, which claims that the level of success of teacher performance can be observed from the educational supervisory 
activity by the principal as a supervisor in the field with the supervision techniques employed in supervision activities.

According to this explanation, the implementation of clinical supervision at the study site, SMA Sub Rayon 18 Palembang, highlights several areas of clinical supervision. This is required so that instructor performance may be measured against agreed-upon benchmarks.

\section{The Influence of Principal Leadership on Teacher Performance}

According to the findings of this study, the principal's leadership has a considerable impact on teacher performance. These findings back up the idea that the principal's leadership has a major impact on teacher performance. The findings of this study show that effective principal leadership leads in improved teacher performance because a competent leader motivates teachers to work hard to attain the vision, purpose, and shared goals.

The principal's leadership is critical in enhancing teacher performance; as a leader, a principal must be able to move, direct, and motivate educators to work properly in line with their tasks and obligations in order to reach the shared goals that have been established. Teacher performance cannot be separated from the principal's leadership, because principals are expected to be able to collaborate with their subordinates, who in this case are teachers. Principals are also expected to set a good example for teachers, and to protect, protect, and solve problems in accordance with the principal's role as a leader or leader.

According to the opinion (Jaliah et al., 2020) that there is a significant influence between the principal's leadership and teacher performance, teacher performance can be improved by the principal's leadership role; the better the principal's leadership role, the better the performance of a teacher. According to the findings (Mahendra et al., 2020), principal leadership has a considerable effect on teacher performance. The principal's leadership must be accountable, because one of the determining factors in educator productivity and morale is the principal's leadership, specifically the extent to which the principal can create a safe and comfortable work environment in order to increase educators' enthusiasm to improve their performance.

According to research (Rohani et al., 2020), there is a positive and significant influence between the principal's leadership and teacher performance. The principal's leadership is shown from the indicators of the principal as an educator, as an educator, as a mover, and as a supervisor has been improved and will be followed by better teacher performance, and vice versa if the principal's leadership decreases, followed by a decrease in teacher performance. Principals can direct educators in developing educational plans, educators can make educational activities active and interesting, there are educational media that correspond to the material being taught, and the educational strategies used are varied and interesting for students, and teachers master the teaching materials. in depth so that it does not cause problems when applied to students, both theoretically and in students' everyday lives, the principal helps educators so that they may publish scientific research journals in order to expand their knowledge.

Based on this research, we can conclude that if the principal provides effective leadership, educators will be willing to work and alter mindsets, attitudes, and behavior in order to enhance their performance. According to Hapizoh et al, (2020), the success or failure of the school is intimately tied to the success or failure of the principal's leadership. The reason for this is the 
principal's strategic function as someone who decides the school's success or failure as an organization to fulfill the vision, purpose, and goals of the school itself, both effectively and efficiently.

According to the study's findings, the principal's leadership has a considerable impact on teacher performance. This indicates that the better and higher the principal's leadership, the better and higher the teacher performance at SMA Sub Rayon 18 Palembang, and vice versa, if the principal's leadership is reduced, the worse the teacher performance. Principal leadership is an essential indication of teacher success; a principal must be able to increase the performance of teachers and their subordinates by demonstrating strong leadership. A principal must be able to persuade teachers to carry out their responsibilities efficiently in order for their performance to improve.

\section{The Effect of Clinical Supervision and Principal Leadership on Teacher Performance}

According to the study's findings, clinical supervision and principal leadership had a substantial impact on teacher effectiveness. These findings back up the idea that clinician supervision and principal leadership have a major impact on teacher performance.

Clinical supervision that is centered on the requirements of educators and is done on a regular basis, as well as effective principal leadership, can help to enhance teacher performance. As a result, in order to attain maximal educational goals, clinical monitoring and principal leadership should be strengthened. This study solely looks at clinical supervision and the leadership of principals as variables impacting teacher performance. There are more aspects that influence teacher performance. Motivation, corporate culture, work discipline, the interaction between educators and leaders, the work environment, and other factors that influence teacher effectiveness must all be examined (Susmadiana et al, 2021).

The findings of this study are consistent with those of (Saddi et al., 2021), who found a favorable association between principal supervision and teacher performance. Salma (2018) concludes in his research that there is a favorable and substantial connection between the leadership of the madrasah principal and clinical supervision combined on teacher performance.

Clinical supervision is used to improve teacher effectiveness. Clinical supervision directs, guides, and fosters educators in carrying out a quality education process. Clinical supervision carried out by school administrators helps teachers overcome obstacles and feels guided by school principals so that they may increase the quality of their education (Gusmiyati et al, 2021).

The findings of this study demonstrate that a teacher's performance may be enhanced if certain parameters, both internal and external to the instructor, are adjusted. According to Murtiningsih et al, (2019), variables influencing teacher performance include the degree of teacher education, teaching supervision, upgrading programs, a congenial atmosphere, facilities and infrastructure, physical and mental health of educators, the principal's leadership style, and others. The principal is in charge of offering, directing, and overseeing teaching and learning activity programs, as well as conducting research on challenges connected to enhancing teaching and learning activity programs so that educational goals may be met optimally. Clinical supervision is used here. Clinical supervision takes place in a face-to-face relationship 
Volume 3 (2) 2022

E-ISSN: 2723-6919 P-ISSN: 2746-0827

between the principal and the teacher and is focused on the problems faced by teachers with the goal of improving teacher difficulties in the classroom in order to improve teacher performance and professionalism.

To overcome the problems that educators face, an open, creative attitude, high morale, and a pleasant work environment are required. This is very closely related to the principal's leadership, specifically how the principal carries out the principal's leadership in order to create a comfortable environment for educators. Leadership is the act of someone who directs the activity of a group in order to attain a common objective (Kristiawan et al, 2019). As a strong leader, the principal must be able to communicate effectively with educators in order to adapt and inspire educators to perform well in line with the organization's vision, purpose, and goals, as well as providing appropriate examples and examples (Desrina et al, 2020).

\section{Conclusion}

Based on the findings of the data analysis, it is possible to infer that clinical supervision and principal leadership have a favorable and substantial influence on teacher performance at SMA Sub Rayon 18 Palembang, either partially or jointly. The better clinical supervision is implemented and supported by competent principal leadership, the better the teacher's performance will be.

\section{E. Acknowledgement}

We Thank to Principal of SMA Negeri 19 Palembang, at SMA Sub Rayon 18 Palembang, Rector Universitas PGRI Palembang, Director of Postgraduate Program and Chief of Study Program Management of Education Universitas PGRI Palembang and friends who have helped us to do this meaningful project.

\section{References}

Bungin, B. (2010). Metodologi Penelitian Kuantitatif [Quantitative Research Methodology]. Raja Grafindo Perkasa.

Desrina, D., Fitria, H., \& Mulyadi, M. (2020). The Relationship between Principal Supervision and Interpersonal Communication with the Work Ethic of Teachers. Journal of Social Work and Science Education, 1(2), 161-167. https://doi.org/10.52690/jswse.v1i2.45

Gusmiyati, G., Lian, B., \& Fitria, H. (2021). Principal's Supervision in Improving Teacher's Performance. Journal of Social Work and Science Education, 2(1), 83-94. https://doi.org/10.52690/jswse.v2i1.209

Hapizoh, H., Harapan, E., \& Destiniar, D. (2020). Pengaruh Profesionalisme Guru Dan Supervisi Kepala Sekolah Terhadap Kinerja Guru [The Influence of Teacher Professionalism and Principal Supervision on Teacher Performance]. JMKSP (Jurnal Manajemen, Kepemimpinan, Dan Supervisi Pendidikan), 5(2), 168.

Hasanah, M. L., \& Kristiawan, M. (2019). Supervisi Akademik dan Bagaimana Kinerja Guru [Academic Supervision and How Teachers Perform]. Tadbir : Jurnal Studi Manajemen Pendidikan, 3(2), 97. https://doi.org/10.29240/jsmp.v3i2.1159 
Isherwood, G. B. (1983). Clinical supervision: A Principal's Perspective. Journal of Educational Administration, 21(1), 14-20. https://doi.org/10.1108/eb009865

Jaliah, J., Fitria, H., \& Martha, A. (2020). Pengaruh Kepemimpinan Kepala Sekolah dan Manajemen Kepala Sekolah terhadap Kinerja Guru [The Influence of Principal Leadership and Principal Management on Teacher Performance]. Journal of Education Research, 1(2), 146-153. https://doi.org/10.37985/joe.v1i2.14

Kristiawan, M., Yuniarsih, Y., Fitria, H., \& Refika, N. (2019). Supervisi pendidikan [Education supervision]. Bandung: Alfabeta.

Lestari, I. D. (2019). Implementasi Supervisi Klinis Untuk Meningkatkan Kinerja Guru [Implementation of Clinical Supervision to Improve Teacher Performance]. 6(2), 129134.

Lian, B., Fitria, H., \& Zulfakar. (2020). Implementasi Supervisi Akademik dalam Meningkatkan Kinerja Guru [Implementation of Academic Supervision in Improving Teacher Performance]. Jurnal Manajemen, Kepemimpinan, Dan Supervisi Pendidikan) P-ISSN: 2548-7094 E-ISSN 2614-8021, 5(2).

Mahendra, Arafat, Y., \& Setiawan, A. A. (2020). Pengaruh Motivasi Kerja Guru, Dan Kepemimpinan Kepala Sekolah Terhadap Kinerja Guru [The Influence of Teacher's Work Motivation and Principal's Leadership on Teacher Performance]. Islamic Education Journal, 1(3), 271-292.

Majid, A. (2016). Pengembangan Kinerja Guru [Teacher Performance Development]. Samudra Biru.

Mulyasa, E. (2019). Menjadi Kepala Sekolah Profesional [Become a Professional School Principal]. Remaja Rosdakarya.

Murtiningsih, M., Kristiawan, M., \& Lian, B. (2019). The Correlation Between Supervision of Headmaster and Interpersonal Communication With Work Ethos of the Teacher. European Journal of Education Studies.

Priansa, D. J., \& Setiana, S. S. (2018). Manajemen dan Supervisi Pendidikan [Education Management and Supervision]. Bandung. Alfabeta

Renata, Wardiah, D., \& Kristiawan, M. (2018). The Influence of Headmaster's Supervision and Achievement Motivation on Effective Teachers. International Journal of Scientific and Technology Research, 7(6), 44-49.

Riduwan. (2020). Dasar-Dasar Statistika [Statistical Basics]. Bandung: Alfabeta.

Rohani, I., Fitria, H., \& Rohana, R. (2020). Pengaruh Kepemimpinan Kepala Sekolah dan Disiplin Kerja Guru terhadap Kinerja Guru SDN di Kecamatan Sembawa [The Influence 
of Principal Leadership and Teacher Work Discipline on the Performance of SDN Teachers in Sembawa District]. Jurnal Pendidikan Tambusai, 4(3), 1883-1894.

Saddi, E., Simbolon, B., \& Kailola, L. G. (2021). Pengaruh Kepemimpinan Kepala Sekolah Dan Supervisi Terhadap Kinerja Guru Pada Sma Kristen Barana' (Studi Kasus Di SMA Kristen Barana Kabupaten Toraja Utara) [The Effect of Principal Leadership and Supervision on Teacher Performance at Barana Christian High School (Case Study at Barana Christian High School, North Toraja Regency)]. Jurnal Pendidikan Tambusai, 5, 493-500.

Salma, P. (2018). Pelaksanaan Supervisi Klinis dalam Meningkatkan Kompetensi Profesional Guru di MAN Beureunuen [Implementation of Clinical Supervision in Improving Teacher Professional Competence at MAN Beureunuen]. Jurnal Magister Administrasi Pendidikan. 6(1). 18-23

Saniyem, Sunandar, \& Juliejantiningsih, Y. (2020). Pengaruh Kepemimpinan Dan Supervisi Kepala Sekolah Terhadap Kinerja Guru Taman Kanak-Kanak Di Kecamatan Boja Kabupaten Kendal [The Effect of Principal's Leadership and Supervision on Kindergarten Teacher Performance in Boja District, Kendal Regency]. 9(April), 131149.

Santi, S. (2019). Gaya Kepemimpinan dan Pelaksanaan Supervisi Kepala Sekolah Untuk Meningkatkan Kinerja Guru [Leadership Style and Implementation of Principal Supervision To Improve Teacher Performance]. Didaktis: Jurnal Pendidikan Dan Ilmu Pengetahuan, 19(2), 113-131. https://doi.org/10.30651/didaktis.v19i2.2825

Sugiyono. (2019). Metode Penelitian Kuantitatif, Kualitatif, dan $R \& D$ [Quantitative, Qualitative, and $R \& D$ Research Methods]. Bandung: Alfabeta.

Susmadiana, S., Lian, B., \& Puspita, Y. (2021). The Effect of Managerial Supervision and Work Motivation on Improving Principal's Performance. Journal of Social Work and Science Education, 2(2), 181-187. https://doi.org/10.52690/jswse.v2i2.248

Utami, S. (2017). Penerapan Supervisi Klinis Untuk Meningkatkan Kinerja Guru dalam Proses Belajar Mengajar Gugus IV Sanankulon [Application of Clinical Supervision to Improve Teacher Performance in the Teaching and Learning Process of Cluster IV Sanankulon]. Jurnal Riset dan Konseptual, 2(3).

Widiyanto, M. A. (2010). Statistika Untuk Penelitian Bidang Teologi, Pendidikan Agama Kristen, \& Pelayanan Gereja [Statistics for Research in Theology, Christian Religious Education, \& Church Services]. Elex Media Komputindo. 